\title{
Economic and Environmental Assessment of Two Different Rain Water Harvesting Systems for Agriculture
}

\author{
Luigi Pari $(\mathbb{D}$, Alessandro Suardi $(\mathbb{D}$, Walter Stefanoni $(\mathbb{D}$, Francesco Latterini $(\mathbb{D}$ and Nadia Palmieri $* \mathbb{D}$
}

Citation: Pari, L.; Suardi, A.; Stefanoni, W.; Latterini, F.; Palmieri, N. Economic and Environmental Assessment of Two Different Rain Water Harvesting Systems for Agriculture. Sustainability 2021, 13, 3871. https://doi.org/10.3390/ su13073871

Academic Editor: Hossein Azadi

Received: 10 March 2021

Accepted: 26 March 2021

Published: 31 March 2021

Publisher's Note: MDPI stays neutral with regard to jurisdictional claims in published maps and institutional affiliations.

Copyright: (c) 2021 by the authors. Licensee MDPI, Basel, Switzerland. This article is an open access article distributed under the terms and conditions of the Creative Commons Attribution (CC BY) license (https:// creativecommons.org/licenses/by/ $4.0 /)$.
Consiglio per la Ricerca in Agricoltura e l'analisi dell'Economia Agraria (CREA) - Centro di Ricerca Ingegneria e Trasformazioni Agroalimentari, Via della Pascolare 16, Monterotondo, 00015 Rome, Italy; luigi.pari@crea.gov.it (L.P.); alessandro.suardi@crea.gov.it (A.S.); walter.stefanoni@crea.gov.it (W.S.); francesco.latterini@crea.gov.it (F.L.)

* Correspondence: nadia.palmieri@crea.gov.it; Tel.: +39-069-067-5219

\begin{abstract}
Increasing aridity and subsequent water scarcity are currently among the major problems of agriculture. Rainwater harvesting could represent a way to tackle this issue, and, as a consequence, scientific research has been more and more focused on such topic. On the other hand, few scientific studies related to economic and environmental assessment of rainwater harvesting systems in agriculture are available. The present study carried out an economic and environmental analysis of two different systems for rainwater harvesting: a typical pond and an innovative flexible water storage system (FWSS). The environmental and economic performance of the systems was compared using the Life Cycle Assessment (LCA) and Life Cycle Costing (LCC) methodologies, referring to a functional unit (FU) of $1 \mathrm{~m}^{3}$ of storable water. The FWSS showed better environmental end economic

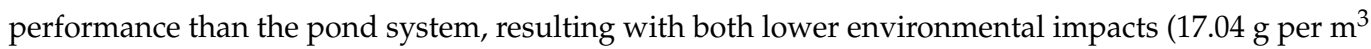

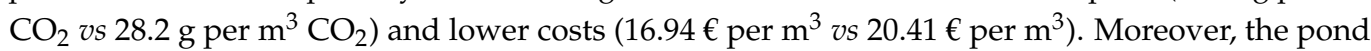
system was more impactful than the FWSS for all the 17 categories investigated. Therefore, the FWSS can be a suitable solution for water harvesting in agriculture sector, showing interesting features for farmers.
\end{abstract}

Keywords: ecoefficiency; life cycle assessment (LCA); life cycle costing (LCC); run-off; pond; flexible water storage system

\section{Introduction}

Water scarcity and water supply are among the major concerns that countries worldwide have been struggling to address during the last decades. Usually, European countries are not arid, but some, like Cyprus, Bulgaria, Belgium, Spain, Malta and Italy, are currently exploiting $20 \%$ or more of their long-term water supplies every year. Agriculture is among the main responsible sector for freshwater consumption accounting for the $24 \%$ of the abstracted water that can go up to $80 \%$ in southern regions [1]. The need to rely on natural fresh water basins or on underground water is further fostered by the effect of climate change on the rainfall pattern in the Mediterranean region, where heavy rainfall events are occurring more frequently and only in a limited period of the year [2]. Farmers struggle to plan field activities, and plants need to be irrigated artificially more often than before. They mainly rely on underground water, but the overexploitation of such resource has detrimental effects on the environment [3]. Public awareness of agriculture impact on the environment is driving the change from conventional farming to organic farming, the latter of which seeks to burden the environment with as little water depletion as possible [4]. Although organic farming also contributes to GHGs reduction, it is not the resolutive strategy to cope with this problem. Interest is growing in arid and semi-arid regions of the planet concerning the possibility of collecting and storing rainwater for urban and agriculture purposes [5]. 
The present water scarcity leads to a new paradigm in water resource management, and the application of sustainable water supply solutions is essential $[6,7]$. Some studies $[8,9]$ have catalyzed interest in alternative approaches to ensure water security by applying, for example, rainwater harvesting systems.

Rain water harvesting (RWH) is the process of accumulating incident raindrops on ground surfaces and roofs, with the help of cisterns, tanks, and underground check dams [10]. RWH has been applied for centuries by humankind to meet water supply needs and nowadays can still represent an important practice to improve the efficiency of the use of water in the urban future [5] by reducing household expenditures on water consumption [11] and offering many opportunities for agriculture.

In fact, irrigation of rainfed crops through RWH could represent a good option to increase crop yields due to an improvement in the water productivity [5].

Jiang et al. (2013) highlighted that the rainwater supplementary irrigation could increase crop yield by more than 30\% [12]. Furthermore, even if rainfed agriculture in arid and semi-arid areas represents to up to $90 \%$ of the total production of cereal of these regions, in many countries, productivity remains low due to the sub-optimal rainfall characteristics, disadvantageous land conditions, and a deficiency in good management of these resources. On the other hand, increasing productivity of rainfed areas could lead to an increase in food security, reduction in irrigation frequency, and improvement in livelihoods and rural conditions. Furthermore, as reported by Ghimire et al. (2017) [13], RWH could reduce "impacts on the environment and human health, stormwater runoff and combined sewer overflows, and economic viability". As observed by various authors, RWH represents a valid system to reduce stormwater runoff, improving water management in an affordable manner [14-16]. Surface runoff is a phenomenon that, at the farm level, is triggered by 10 to $25 \%$ of rainwater falling in arid and semi-arid areas, and it can have negative effects on soil erosion and the accumulation of nutrients, chemicals, and sediments into rivers and streams [5]. Storage can be achieved with various types of storage systems that can also differ remarkably in terms of costs and environmental impacts [5].

Nevertheless, the environmental sustainability of different strategies to store rainwater has been seldomly investigated at the farm level; particularly, it has not been taken into account in the decision-making phase which should include this aspect along with the economical and feasibility aspects. Only few studies dealt with the environmental aspect of fresh water storage system, and, if so, they mainly focused on drinkable water $[17,18]$. Because agriculture is a highly demanding activity in fresh water (more than a simple beverage), much attention is ought to be paid to such aspect. Life Cycle Analysis (LCA) is widely recognized as a standardized method $[19,20]$ that is used to evaluate the potential environmental impacts of products, processes, or services during the entire life cycle. Similar to LCA, Life Cycle Costing (LCC) methodology [21,22] is one of the main tools used to embed economic factors into the assessment of sustainability.

In general, as noted by several authors, irrigation in agriculture also leads to increased environmental impacts [23-26]. Most of the works in the literature focus on the emissions generated by the irrigation phase, focusing mainly on the amount of water resources used or on the energy related to the irrigation phase $[23,24]$, and often without specifically analyzing the infrastructure (irrigation system) used [25,26].

On the other hand, some studies assessed the sustainability of rain water supply systems. Yan et al. (2018) [9] compared the environmental impacts of decentralized and centralized potable water supply, and they found a water-saving efficiency laying between 0.6 and $100 \%$, depending on rainfall. Their results suggested that potable water produced from this decentralized system currently performs poorer than centralized water from an environmental perspective [9]. Other authors [8] performed a comparative LCA for greywater treatment within a circular economy framework and evaluated the environmental impacts of three greywater treatment alternatives (i.e., photocatalysis, photovoltaic solar-driven photocatalysis, and membrane biological reactor). Their results showed that 
photovoltaic photocatalysis driven by solar energy is the most sustainable scenario from the environmental point of view [8].

In this scenario, the implementation of a circular economy strategy results in a promising approach [8]. However, LCA studies performed relying on experimental data for the analysis of the environmental impacts of crops irrigated with reclaimed water are still missing [27], although irrigation plays a critical role in boosting crop yield; furthermore, $40 \%$ of freshwater global resources are consumed by agricultural production [28].

In particular, to the best of our knowledge, the literature lacks LCA and LCC studies concerning the impact of RWH systems for agricultural purposes, particularly as tool in the decision-making process. In this paper, the authors investigated the environmental and economic impact of a conventional water storage system, as a pond, against an innovative flexible water storage system (FWSS) that could bring about practical advantages to farmers because of its flexibility and the easy-to-move feature. A comparison has been performed via LCA and LCC assessment starting for the hypothesis that $400 \mathrm{~m}^{3}$ (average commercial pond's volume capacity available on the market) of rainwater can be collected and stored locally for crop irrigation purposes. Furthermore, there are not studies evaluating the ecoefficiency of different rainwater harvesting systems. For this reason, this study fills a knowledge gap in the current literature.

\section{Materials and Methods}

Farms usually rely on underground reservoir or on aqueduct or, sometime, on channels that naturally occur outside the field during the winter to pump the water needed for watering plants or cleaning machineries. All those sources are temporary available. Thus, it is important to catch as much water as possible during the fall-winter season and store it for the following dry season.

Water storage in ponds is quite common in farms. Thus, the research focused on the economic and environmental sustainability assessment of two systems for water harvesting and storage: the pond and the flexible water storage system (FWSS) (Figure 1).
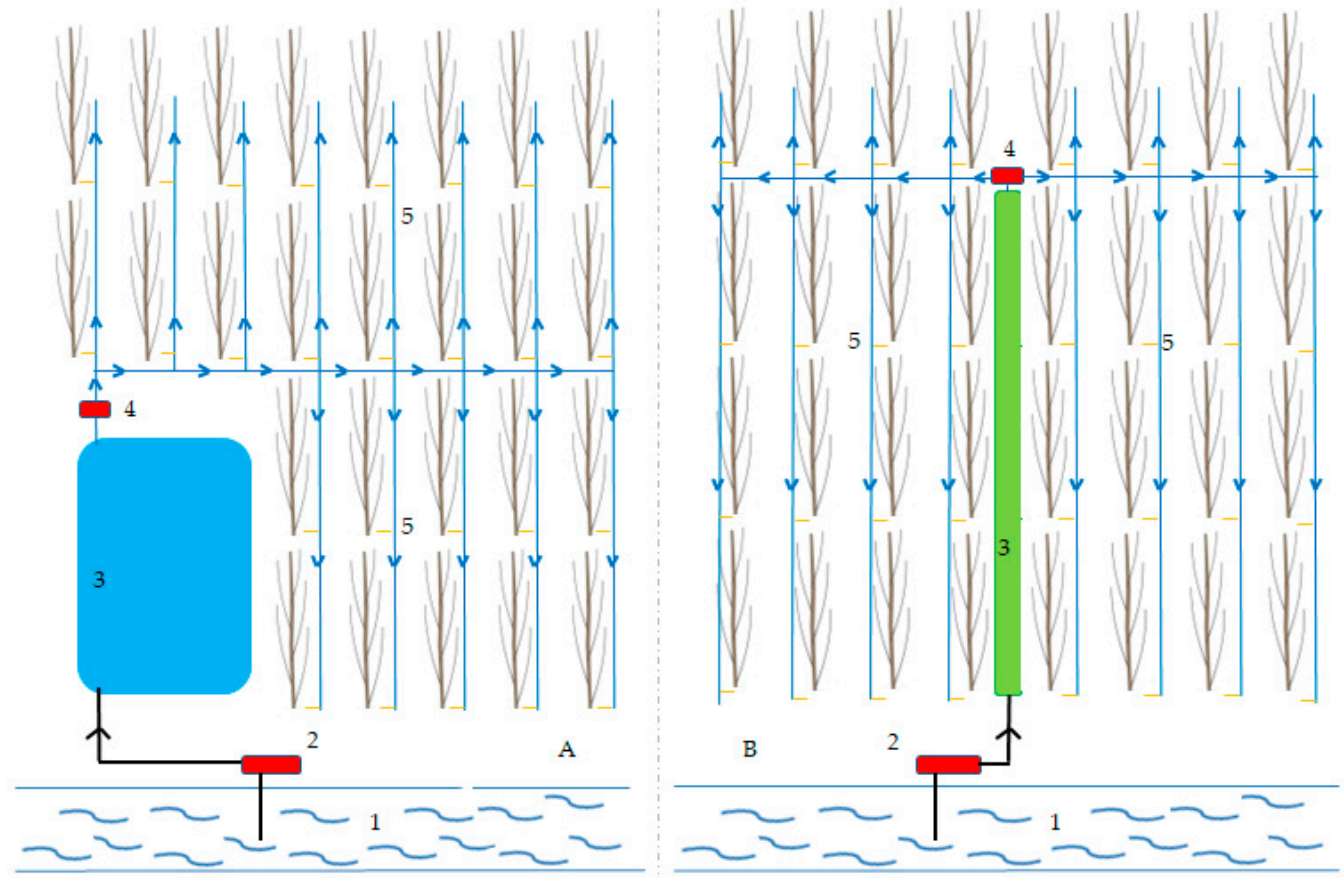

Figure 1. Schematic view of the pond (A) and the FWSS (B) meant for agroforestry application. Numbers refer to the main components of both systems: (1) seasonal water stream, (2) loading system (including electric pump, pipes and connections), (3) water storage system, (4) electric pump for water delivery, (5) water usage (e.g., irrigation system). 


\subsection{Pond}

Ponds represent a common strategy for water storage because they are relatively easy to build and low demanding in maintenance although they exhibit short lifespan of 5-10 years that could represent a limit for the system [29]. Furthermore, there are other drawbacks that usually are not taken into account like the permanent disturbance of the soil, the reduction of the arable surface which reduces the available arable land and other concerns related to water quality and safety. Moreover, in areas with high evaporation potential ponds are not very suitable [30] and need to be covered with shade net [29].

Building a pond implies permanent changes in the soil, particularly the shallower horizons which are more fertile and suitable for cropping. In order to accommodate the assumed $400 \mathrm{~m}^{3}$ of water, authors made the hypothesis of removing an equivalent volume of soil $\left(336.6 \mathrm{~m}^{2}\right.$ and $1.4 \mathrm{~m}$ depth) by using a $90-\mathrm{kW}$ excavator. According to the estimations, digging requires $20.5 \mathrm{~h}$ and $328.1 \mathrm{l}$ of fuel (data not shown). Consequently, a double layer $1350 \mathrm{~g} \mathrm{~m}^{-2}$ PVC is applied. A detailed list of the components is shown in Table 1.

Table 1. Summary table of components involved in the loading, storing and water distribution in the pond system.

\begin{tabular}{|c|c|c|c|c|c|c|}
\hline \multirow[t]{2}{*}{ Item } & \multirow[t]{2}{*}{ Unit } & \multirow[t]{2}{*}{ Quantity } & \multicolumn{2}{|c|}{ Unitary Weight (kg) } & \multicolumn{2}{|c|}{ Total Weight (kg) } \\
\hline & & & $\begin{array}{l}\text { Polyvinyl } \\
\text { Chloride }\end{array}$ & Metal & $\begin{array}{l}\text { Polyvinyl } \\
\text { Chloride }\end{array}$ & Metal \\
\hline \multicolumn{7}{|l|}{ Loading system } \\
\hline Electric water pump & (n) & 1.00 & - & 7.02 & & 7.02 \\
\hline Electric cable & (m) & 30.00 & 0.11 & 0.07 & 3.24 & 2.16 \\
\hline Socket & (n) & 1.00 & 0.12 & 0.06 & 0.12 & 0.06 \\
\hline Pipe connection-equal elbow & (n) & 2.00 & 0.18 & & 0.35 & \\
\hline Pipe connection-adapter & (n) & 4.00 & 0.15 & & 0.60 & \\
\hline Anti-cross flow & (n) & 1.00 & 0.16 & & 0.16 & \\
\hline Ball valve & (n) & 2.00 & 0.18 & & 0.35 & \\
\hline Pipe & $(\mathrm{m})$ & 330.00 & 0.31 & & 102.30 & \\
\hline \multicolumn{7}{|l|}{ Pond } \\
\hline Double PVC layer & $\left(\mathrm{m}^{2}\right)$ & 477.56 & 2.35 & & 1122.27 & \\
\hline Fuel & $(\mathrm{n})$ & 328.1 & & & 328.10 & \\
\hline \multicolumn{7}{|l|}{ Irrigation system } \\
\hline Electric water pump & (n) & 1.00 & & 7.02 & & 7.02 \\
\hline Electric cable & (m) & 330.00 & 0.11 & 0.07 & 35.64 & 23.76 \\
\hline Pipe connection-equal elbow & (n) & 2.00 & 0.13 & & 0.26 & \\
\hline Pipe connection-adapter & (n) & 4.00 & 0.11 & & 0.45 & \\
\hline Ball valve & (n) & 2.00 & 0.13 & & 0.26 & \\
\hline Pipe & (n) & 400.00 & 0.23 & & 93.00 & \\
\hline Dripper & (n) & 135.00 & 0.02 & & 2.70 & \\
\hline Total & & & & & 1689.79 & 40.01 \\
\hline
\end{tabular}

The Flexible Water Storage System

The flexible water storage system (FWSS) is an alternative solution to ponds. Interestingly, it can be easily folded and moved elsewhere according to the domestic needs of the farm; the installation does not require a concrete base, just a little slope is desired to ease the outflow of the water, which is ensured by a secondary electric pump, though. Contrary to the pond, water is not directly exposed to sunlight; thus microbial activities are not promoted and higher water quality is expected [31].

The Flexible Water Storage System is made of polyvinyl chloride (PVC) $930 \mathrm{~g} \mathrm{~m}^{-2}$ thick and equipped with inlet and outlet pipe connections. FWSSs find many applications in agricultural sector for storing non-potable water, wastewater or sewage water produced by livestock. According to Rigamonti et al. (2019) the service life of a rain water harvesting system based on a polyethylene storage tank is 50 years [32]. Loading is performed by an electric water pump that pumps the water via a filter from a near seasonal water stream directly into the FWSS. When the tank reaches its maximum capacity, the blow-off valve 
opens preventing over-pressure. The water can be stored as long as it is needed without leak of water or smell. During the dry season the water can be used for irrigation to reduce the exploitation of the underground water. Components of the FWSS are listed in Table 2.

Table 2. Summary table of components involved in the loading, storing and water distribution in the FWSS.

\begin{tabular}{|c|c|c|c|c|c|c|}
\hline \multirow[t]{2}{*}{ Item } & \multirow[t]{2}{*}{ Unit } & \multirow[t]{2}{*}{ Quantity } & \multicolumn{2}{|c|}{ Unitary Weight (kg) } & \multicolumn{2}{|c|}{ Total Weight (kg) } \\
\hline & & & $\begin{array}{l}\text { Polyvinyl } \\
\text { Chloride }\end{array}$ & Metal & $\begin{array}{l}\text { Polyvinyl } \\
\text { Chloride }\end{array}$ & Metal \\
\hline \multicolumn{7}{|l|}{ Loading system } \\
\hline Electric water pump & (n) & 1.00 & & 7.02 & & 7.02 \\
\hline Electric cable & (m) & 30.00 & 0.11 & 0.07 & 3.24 & 2.16 \\
\hline Socket & (n) & 1.00 & 0.12 & 0.06 & 0.12 & 0.06 \\
\hline Pipe connection-equal elbow & (n) & 2.00 & 0.18 & & 0.35 & \\
\hline Pipe connection-adapter & (n) & 4.00 & 0.15 & & 0.60 & \\
\hline Anti-cross flow & (n) & 1.00 & 0.16 & & 0.16 & \\
\hline Ball valve & (n) & 2.00 & 0.18 & & 0.35 & \\
\hline Pipe & $(\mathrm{m})$ & 330.00 & 0.31 & & 102.30 & \\
\hline \multicolumn{7}{|l|}{ FWSS } \\
\hline Plastic fabric HPVi09 & $\left(\mathrm{m}^{2}\right)$ & 678.84 & 0.93 & & 631.32 & \\
\hline Pipe connection-reducer & (n) & 2.00 & 0.30 & & 0.60 & \\
\hline Lid & (n) & 1.00 & 0.35 & & 0.35 & \\
\hline Blow-off valve & (n) & 1.00 & 0.15 & 0.29 & 0.15 & 0.29 \\
\hline Ball valve & (n) & 4.00 & & 0.80 & & 3.20 \\
\hline \multicolumn{7}{|l|}{ Irrigation system } \\
\hline Electric water pump & (n) & 1.00 & & 7.02 & & 7.02 \\
\hline Electric cable & (m) & 330.00 & 0.11 & 0.07 & 35.64 & 23.76 \\
\hline Pipe connection-equal elbow & (n) & 2.00 & 0.13 & & 0.26 & \\
\hline Pipe connection-adapter & (n) & 4.00 & 0.11 & & 0.45 & \\
\hline Ball valve & (n) & 2.00 & 0.13 & & 0.26 & \\
\hline Pipe & (n) & 400.00 & 0.23 & & 93.00 & \\
\hline Dripper & (n) & 135.00 & 0.02 & & 2.70 & \\
\hline Total & & & & & 871.84 & 43.50 \\
\hline
\end{tabular}

\subsection{LCA and LCC Methods}

The environmental impact analysis was carried out using the life cycle assessment methodology (LCA) according to UNI EN ISO 14040:2006 [19] and UNI EN ISO 14044:2006 [20], including the following statements: (a) Goal definition and scoping; (b) life cycle inventory; (c) life cycle impact assessment; (d) life cycle interpretation and improvement. Moreover, the study followed the steps in LCA with the corresponding steps in life cycle costing (LCC) introduced in parallel. Life cycle costing (LCC) is a methodology that aimed to assess the costs across the entire life cycle of a product [33] focusing on the cost at each stage [34].

2.2.1. Boundary of the System for the Life Cycle Assessment (LCA) and Life Cycle Costing (LCC) Analysis

The considered system (for LCA and LCC analysis) is defined by all the processes that occurred during the production and installation phases of two different water tanks (Figure 1). The functional unit is $1 \mathrm{~m}^{3}$ of storable water of the studied RWH systems. It represents the reference unit used to quantify all inputs and outputs from the studied systems [9].

\subsubsection{Life Cycle Inventory Analysis}

Primary data of the materials used for the construction of the pond were obtained through interviews to local enterprises, which main activity consists of ponds' construction or, in general, digging jobs. For the FWSS, the primary data was calculated according to $[35,36]$. Secondary data were obtained by Simapro code database 8.0.2 (Prè Consultants, Amersfoort, The Netherlands) (Tables 3 and 4). 
Table 3. Technical data of the pond.

\begin{tabular}{cccc}
\hline Data & $\begin{array}{c}\text { PVC } \\
(\mathbf{k g})\end{array}$ & $\begin{array}{c}\text { Iron } \\
(\mathbf{k g})\end{array}$ & $\begin{array}{c}\text { Diesel } \\
(\mathbf{k g})\end{array}$ \\
\hline $\begin{array}{c}\text { Loading system } \\
\text { Pond }\end{array}$ & 107.11 & 9.23 & 278.89 \\
Irrigation system & 1122.27 & & \\
\hline
\end{tabular}

Source: data collected from either datasheet or direct weighting of spares.

Table 4. Technical data of the FWSS.

\begin{tabular}{cccc}
\hline Data & $\begin{array}{c}\text { PVC } \\
(\mathbf{k g})\end{array}$ & $\begin{array}{c}\text { Iron } \\
(\mathbf{k g})\end{array}$ & $\begin{array}{c}\text { Diesel } \\
(\mathbf{k g})\end{array}$ \\
\hline Loading system & 107.11 & 9.23 & \\
FWSS & 632.42 & 3.49 & \\
Irrigation system & 132.31 & 30.77 & \\
\hline
\end{tabular}

Source: collected from either datasheet or direct weighting of spares.

\subsubsection{Life Cycle Impact Assessment}

Environmental impacts per $\mathrm{m}^{3}$ of storable water was assessed using both ReCiPe2008 [37] and GWP100 methods. In particular, ReCiPe 2008 method includes categories of environmental impact and environmental damage, i.e., at the midpoint and endpoint level. Initially, the inventory data were associated to the midpoint level using factors of characterizations. Lately, they have been converted and clustered into the endpoint level considering three damage categories (i.e., HH, EC, RE damage categories) and by using weighting factors. It is important to underline that it was applied the method ReCipe Endpoint $(\mathrm{H}) /$ Europe ReCipe H/A by considering weighing factors referred to the mean values of the hierarchical perspective. Moreover, GHG emission was chosen to link the environmental issue to the economic aspect of the water harvesting systems in order to determine their eco-efficiency [38]. The carbon footprint was defined as the sum of all GHGs emitted within the system boundary and expressed in $\mathrm{CO}_{2}$ equivalent according to IPCC 2007 method (100-year life span). A parallel economic assessment is integrated with LCA using a life cycle perspective. It is important to underline that the economic sustainability is an important aspect to consider for farmers.

\subsubsection{Economic Assessment}

The possibility of conducting a LCA study integrated with Life cycle costing (LCC) contributes to improve the ecoefficiency of farms [39], and thus reducing their impacts on the environment, while reducing costs [40].

A conventional cradle-to-gate LCC was applied here encompassing the assessment of all costs associated with the life cycle of both RWH systems studied.

The cost of the items included in the analysis referred to raw materials, services, other operating expenses, and labor costs. The economic data (Tables 5 and 6) derive from informal local market as proposed in other studies [41,42].

Table 5. Economic data of the pond.

\begin{tabular}{cc}
\hline Data & $\begin{array}{c}\text { Total } \\
\text { Costs (Euro) }\end{array}$ \\
\hline Loading system & 669.47 \\
Pond & 6356.93 \\
Irrigation system & 1140.37 \\
Total & $\mathbf{8 1 6 6 . 7 7}$ \\
\hline
\end{tabular}

Total costs include raw materials, services, other operating expenses, and labor costs for each step. Source: data retrieved from informal local market. 
Table 6. Economic data of the FWSS.

\begin{tabular}{cc}
\hline Data & $\begin{array}{c}\text { Total } \\
\text { Costs (Euro) }\end{array}$ \\
\hline Loading system & 669.47 \\
FWSS & 4968.00 \\
Irrigation system & 1140.37 \\
Total & $\mathbf{6 7 7 7 . 8 4}$ \\
\hline
\end{tabular}

Total costs include raw materials, services, other operating expenses, and labor costs for each step. Source: data retrieved from informal local market.

\section{Results and Discussion}

A large majority of literature deals with the environmental impact of water management in agriculture purely in terms of water and energy used [23-26].

It is clear that irrigation might tip the scale towards a less sustainable scenario as observed by Stephenson et al. (2010) [23]. Some authors have evaluated the emissions generated by water harvesting systems and the related costs [32], even if the majority of the studies focused on the impact of RWH systems in urban environment [18,43-46].

In fact, rain and storm water harvesting systems are widely used in urban and agricultural areas especially where the weather conditions are unfavorable, with periods of drought alternating with periods characterized by floods and torrential rains. These aspects were already highlighted by Ghimire et al. (2017) that among the benefits of RWH indicated the reduction of stormwater runoff and combined sewers overflows events, as well as the potential impact reduction on the environment and human health, remarking a lack of understanding in the magnitude of these positive effects [13]. This is especially true in agriculture where, to the best of our knowledge, few studies analyzed the environmental and economic impacts of RWH infrastructure.

\subsection{Environmental Assessment}

The impact analysis allowed to identify the RWH infrastructure and its installation which has higher environmental impact. It is important to underline that with the weighing it is possible to assess the importance of each category of impact obtaining aggregate results as damage categories [47]; while the characterization permits to quantify the general impacts concerning different impacts categories [47].

Figure 2 reports the LCA results of each studied RWH system at endpoint level. Comparing the outcomes of weighing (Figure 2) and characterization (Figure 3) helps to identify the environmental performance and impacts of each RWH system. The highest damage categories were resources and human health, while ecosystem damage was the lowest in all systems.

The pond causes the highest impact on resources and human health due to used raw material. Polyvinyl chloride (PVC) production had the highest impact on all damage categories (especially in the pond system); this finding was due to the characteristics of PVC production. Additionally, Ghimire et al. (2017) found out that storage tanks represent the second most important cause of environmental impact (after energy usage) [13]. In order to reduce the impacts, the material used for the construction of a RWH device represents an important aspect to take in consideration. This is true also for the life span and volume of the storage tank that may lead to differing impacts [48]. In fact, Ghimire at al. (2014) observed lower impact of polyethylene (PE) when compared with a concrete storage tank, even if the latter has an expected life span of 70 years (50 years for the PE storage tank) [48]. According to Ghimire et al. (2017), the PE storage tank resulted as a good alternative to the RWH fiberglass storage tank that was less sustainable for the ozone depletion and freshwater withdrawal impact categories [13]. However, to the best of our knowledge, no other studies reported information about the specific impact generated by PVC used for RWH construction. 


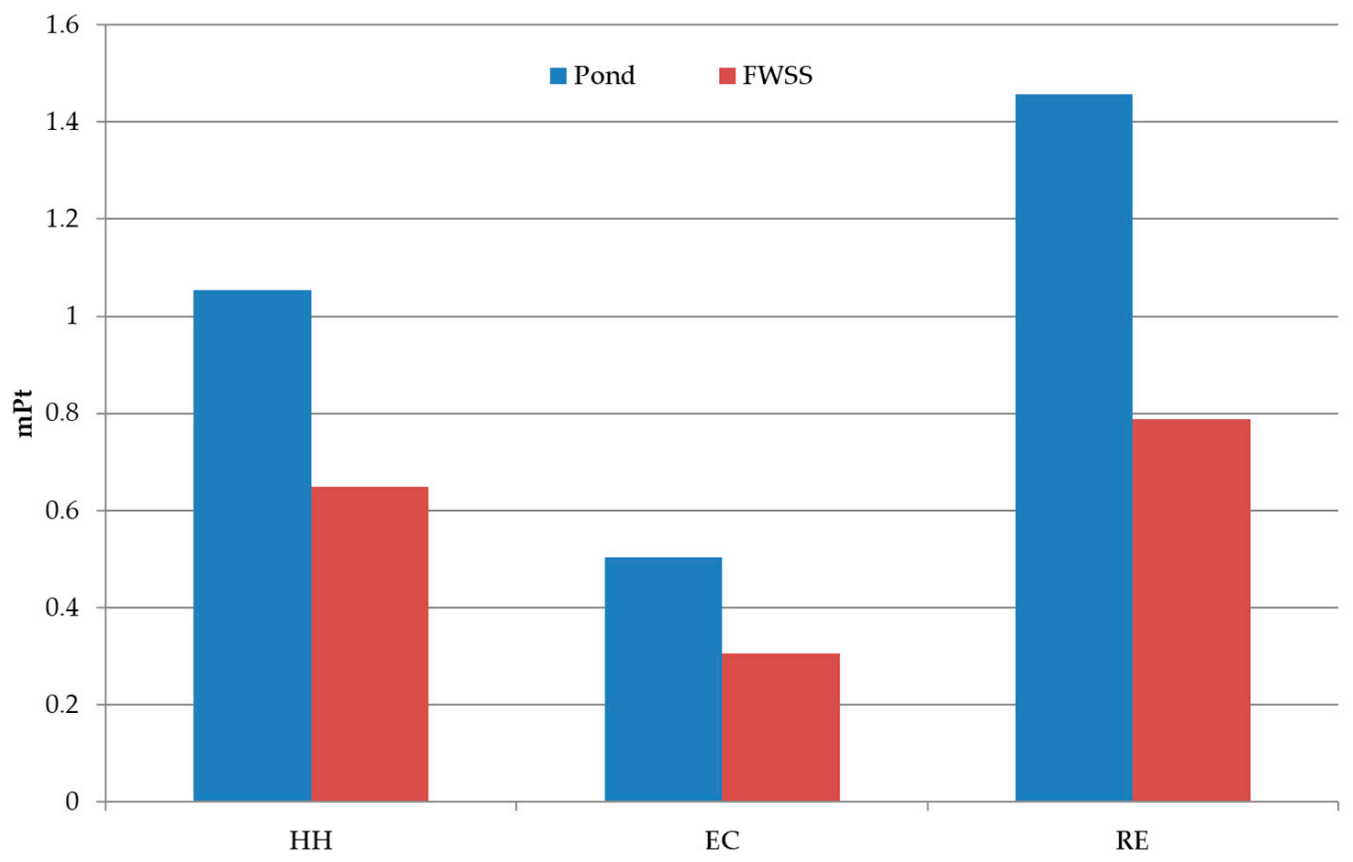

Figure 2. Result of the weighing, comparison of two different RWH systems with functional unit of $1 \mathrm{~m}^{3}$ of storable water. The acronyms of the different damage categories are HH (Human Health), EC (Ecosystem), RE (Resources).

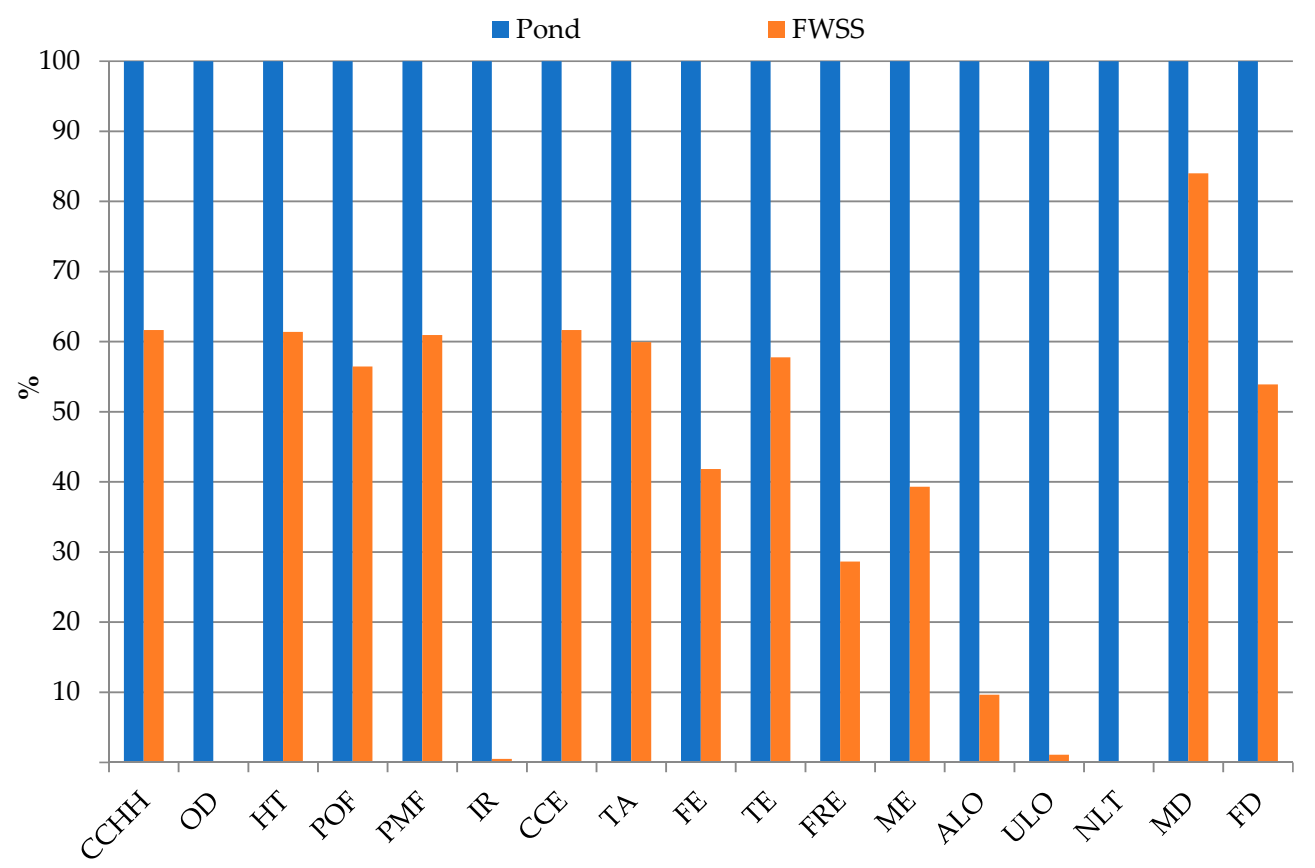

Figure 3. Result of the characterization, comparison of two different runoff water storage systems with functional unit of $1 \mathrm{~m}^{3}$ of storable water. The values are expressed as percentages in relation to the $100 \%$ given to RWH systems with the biggest impact in each category (i.e., Pond $=100 \%$ in all the considered impact categories). The acronyms of the different impact categories are CCHH (climate change human health), OD (ozone depletion), HT (human toxicity), POF (photochemical oxidant formation), PMF (particulate matter formation), IR (ionizing radiation), CCE (climate change ecosystems), TA (terrestrial acidification), FE (freshwater eutrophication), TE (terrestrial ecotoxicity), FRE (freshwater ecotoxicity), ME (marine ecotoxicity), ALO (agricultural land occupation), ULO (urban land occupation), NLT (natural land transformation), MD (metal depletion), FD (fossil depletion). 
The characterization analysis (Figure 3) showed the environmental performance of each RWH system in relative terms reporting midpoint environmental impacts.

The analysis showed that the pond system is more impactful than the FWSS in all impact categories. In particular, PVC production was the most impactful phase (11 out of 17 impact categories) regardless of the RWH system; this was due to the characteristics of the PVC production itself. In particular, for each studied system, the environmental impacts on $\mathrm{CCHH}$ category were due to carbon dioxide emissions coming from PVC production. This production also impacts the HT category (due to dioxin emission), POF (caused by nitrogen oxides emissions), PMF (due to sulfur dioxide emissions), CCE (caused by carbon dioxide emissions) and TA (due to sulfur dioxide emissions) impact categories. Moreover, the PVC production impacts other categories: FE (caused by phosphorus emissions in the water) and TE (due to chlorine emissions) impact categories. In addition, the impact of PVC production on the FRE category was due to nickel emission in the water for the pond system and copper emission (in the water) for the FWSS. The impacts on the ME category were due to chlorine emissions coming from PVC production. Finally, the PVC production also impacted the fossil depletion (FD) category, and this was because of the energy necessary for the production.

It is interesting to observe that 3 out of 17 impact categories (i.e., OD, IR and NLT impact categories) are affected only by environmental impact due to the pond system, while these categories are not involved in the FWSS. In fact, the extraction of oil and the production of fuel and its combustion during the excavation contributed to OD, IR and NLT impact categories only for the pond system.

Moreover, it is important to underline that the pond system is more impactful than the FWSS in the ALO and ULO impact categories due to a different occupation of land between the two water storage systems. In fact, for the same volume of stored water, unlike the pond, the FWSS does not permanently occupy arable land and can be installed on the uncultivated soil of the farm (e.g., over ditches or between rows of permanent crops that do not require machine passage). This is a major advantage especially in farms where space is a limiting factor.

Finally, the impacts on the MD category were due to the irony parts of excavator (used to create the pond), loading and irrigation systems (for both RWH systems).

\subsection{The Economic Aspects and Ecoefficiency Analysis}

The LCC analysis of the water systems was carried out in similar phases corresponding to LCA standard. Table 7 shows the total costs referred to the functional unit of $1 \mathrm{~m}^{3}$ of storable water.

Table 7. The economic aspect of each system per $1 \mathrm{~m}^{3}$ of water.

\begin{tabular}{cc}
\hline Data & $\begin{array}{c}\text { Total } \\
\text { Costs }\left(\boldsymbol{€} \text { per } \mathbf{~ m}^{3}\right)\end{array}$ \\
\hline Pond system & 20.41 \\
FWSS & 16.94 \\
\hline
\end{tabular}

All data are referred to $1 \mathrm{~m}^{3}$. Source: Authors' elaboration.

Findings showed that the FWSS's costs are slightly lower than the pond system's; in fact, the FWSS shows total costs of $16.94 €$ per $\mathrm{m}^{3}$ of storable water, versus $20.41 €$ per $\mathrm{m}^{3}$ in the pond system. The current literature lacks studies dealing with costs of an FWSS, though this is quite obvious considering that this system represents an innovation in the sector, which has not been studied yet. On the other hand, several studies analyzed economic aspects related to ponds' construction for rainwater harvesting, with particular reference to irrigation purposes. A literature review carried out by Lasage et al. (2015) reported an average cost for water storage ponds, with dimensions ranging from 30 to $300 \mathrm{~m}^{3}$, of $17.16 €$ per $\mathrm{m}^{3}$ [49]. This value is slightly lower than what was found in the present study. Surprisingly, this higher cost is not related to the different lining 
material (cement-wire in the cases studied in the review and plastic film in this paper's), considering that cost for lining with cement and wire is generally higher than the cost for the same operation performed with plastic film. Several further studies were carried out especially in India. Reported ponds' construction costs were substantially lower than what was found in the present study. In details, Deshmukh et al. (2016) reported $1.61 €$ per $\mathrm{m}^{3}$ [50], while $3.71 €$ per $\mathrm{m}^{3}$ were found for a pond lined through an HDPE (high-density polyethylene) geomembrane by Reddy at al., (2020) [51]. Finally, Shalander et al. (2016) reported construction costs for unlined ponds in India ranging from 1.80 to $4.35 €$ per $^{3}$ [52]. Such markedly lower construction costs for ponds are related to both the absence of lining material (in most cases) and to the lower labor costs compared to the Italian ones. Interestingly, Shalander et al. (2016) also reported construction costs for a particular rainwater storage system typical of the Jodhpur region, locally named Tanka [52]. This consists of an underground cistern made of concrete. This system is, under some aspects, comparable to the FWSS, considering that water is not stored in direct contact with air. Construction costs of a Tanka resulted equal at $21.25 €$ per $\mathrm{m}^{3}$-therefore higher than FWSS ones, highlighting how such innovative water storage system is also suitable outside of Europeon contexts.

An important aspect of the ecoefficiency analysis of two different water storage systems was the variability of their main components, as was demonstrated by differences in carbon footprint (as an environmental indicator) and life cycle costs (as an economic indicator) in relation to RWH systems.

The highest value of the carbon footprint and costs was obtained for the pond system, while the FWSS exhibited the lowest value of GHG emission and aggregated costs (Figure 4). These findings showed that the FWSS was the best solution under the economic and environmental point of view. In fact, the FWSS and the pond system cost $16.94 €$ with an emission of $17.4 \mathrm{gr} \mathrm{CO}_{2}$ eq per $\mathrm{m}^{3}$ of storable water and $20.41 €$ with an emission of $28.2 \mathrm{gr} \mathrm{CO}_{2}$ eq per $\mathrm{m}^{3}$ of storable water, respectively.

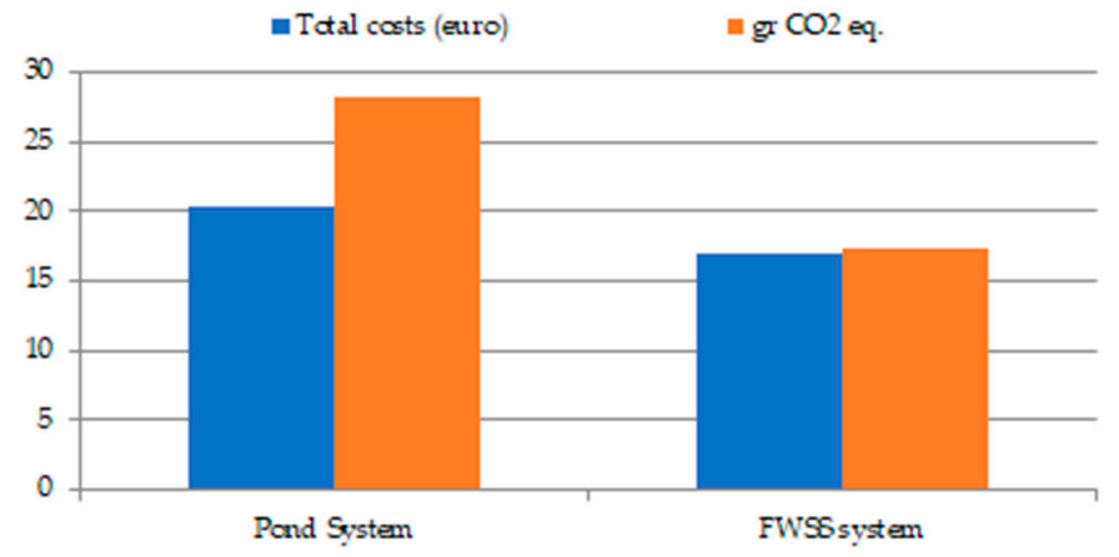

Figure 4. Combined results of the LCC and GWP (LCA analysis) of each RWH system per $\mathrm{m}^{3}$ of storable water. Source: Authors' elaboration.

\section{Conclusions}

The present work aimed to perform the environmental and economic analysis of two different RWH systems for irrigation purposes. In particular, LCA and LCC assessments were carried out to compare, under environmental and economic aspect, the water storage of a typical pond and an innovative flexible water storage system (FWSS). The current literature encompasses only few studies assessing the environmental and economic performance of different rainwater harvesting strategies in agriculture. For this reason, the present work represents a first attempt of such kind of evaluation in the topic-mainly regarding the evaluation of eco-efficiency-and the first step to fulfill such knowledge gap. 
Findings showed that the FWSS performed better in both environmental and economic aspects, resulting in a suitable and sustainable solution for water harvesting in agriculture.

Evaluating the environmental and economic performance of a given system and carrying out comparisons among possible alternatives is crucial for a proper decisionmaking process. Considering the importance of water scarcity and water harvesting topics in a circular economy framework, carrying out this kind of scientific analysis could provide an important contribution to the decision-makers. In particular, our findings are useful not only for academics but also for farmers and practitioners working in the topic of water management.

Further studies should focus on a real case study, providing tangible evaluation of the environmental and economic performance based on existing RWH systems. The sustainability of such system highlighted by our results-along with the valuable features of the FWSS associated with flexibility and nonpermanent disturbance of the environment-paves the way for interesting abroad applications, particularly where water scarcity jeopardizes human health and food security in arid countries of the globe.

Author Contributions: Conceptualization N.P., A.S., W.S. and F.L.; formal analysis, N.P.; investigation, N.P., W.S. and F.L.; data curation and methodology N.P.; writing-original draft preparation N.P., A.S., W.S. and F.L.; In particular, Introduction paragraph, N.P and A.S.; Materials and Methods paragraphs N.P. and W.S.; Results and Discussion paragraph N.P., A.S. and F.L; Conclusions paragraph N.P., A.S., W.S. and F.L.; writing-review and editing N.P., A.S., W.S. and F.L.; supervision, project administration and funding acquisition, L.P. All authors have read and agreed to the published version of the manuscript.

Funding: This research was funded by the AGROENER project (D.D. n. 26329, 1 April 2016) funded by the Italian Ministry of Agriculture (MiPAAF) and the APC was funded by AGROENER project. The ideas expressed do not represent those of the Italian Ministry of Agriculture (MiPAAF).

Conflicts of Interest: The authors declare no conflict of interest.

\section{References}

1. European Environment Agency. Water Scarcity and Drought in the European Union; Rep. KH-30-09-180-EN-D; European Environment Agency: København, Denmark, 2010; p. 6.

2. Benabdelouahab, T.; Gadouali, F.; Boudhar, A.; Lebrini, Y.; Hadria, R.; Salhi, A. Analysis and trends of rainfall amounts and extreme events in the Western Mediterranean region. Theor. Appl. Climatol. 2020, 141, 309-320. [CrossRef]

3. Changming, L.; Jingjie, Y.; Kendy, E. Groundwater Exploitation and Its Impact on the Environment in the North China Plain. Water Int. 2001, 26, 265-272. [CrossRef]

4. Gomiero, T.; Pimentel, D.; Paoletti, M.G. Environmental impact of different agricultural management practices: Conventional vs. organic agriculture. CRC. Crit. Rev. Plant Sci. 2011, 30, 95-124. [CrossRef]

5. Helmreich, B.; Horn, H. Opportunities in rainwater harvesting. Desalination 2009, 248, 118-124. [CrossRef]

6. Uribe, I.O.; Mosquera-Corral, A.; Rodicio, J.L.; Esplugas, S. Advanced technologies for water treatment and reuse. AIChE 2015, 61, 3146-3158. [CrossRef]

7. Wilcox, J.; Nasiri, F.; Bell, S.; Rahaman, M.S. Urban water reuse: A triple bottom line assessment framework and review. Sustain. Cities Soc. 2016, 27, 448-456. [CrossRef]

8. Dominguez, S.; Laso, J.; Margallo, M.; Aldaco, R.; Rivero, M.J.; Irabien, Á.; Ortiz, I. LCA of greywater management within a water circular economy restorative thinking framework. Sci. Total Environ. 2018, 621, 1047-1056. [CrossRef]

9. Yan, X.; Ward, S.; Butler, D.; Daly, B. Performance assessment and life cycle analysis of potable water production from harvested rainwater by a decentralized system. J. Clean. Prod. 2018, 172, 2167-2173. [CrossRef]

10. Krishna, R.S.; Mishra, J.; Ighalo, J.O. Rising Demand for Rain Water Harvesting System in the World: A Case Study of Joda Town, India. World Sci. News 2020, 146, 47-59.

11. Karim, M.R.; Bashar, M.Z.I.; Imteaz, M.A. Reliability and economic analysis of urban rainwater harvesting in a megacity in Bangladesh. Resour. Conserv. Recycl. 2015, 104, 61-67. [CrossRef]

12. Jiang, Z.-y.; Li, X.-y.; Ma, Y.-j. Water and Energy Conservation of Rainwater Harvesting System in the Loess Plateau of China. J. Integr. Agric. 2013, 12, 1389-1395. [CrossRef]

13. Ghimire, S.R.; Johnston, J.M.; Ingwersen, W.W.; Sojka, S. Life cycle assessment of a commercial rainwater harvesting system compared with a municipal water supply system. J. Clean. Prod. 2017, 151, 74-86. [CrossRef]

14. Qi, Q.; Marwa, J.; Mwamila, T.B.; Gwenzi, W.; Noubactep, C. Making rainwater harvesting a key solution for water management: The universality of the Kilimanjaro Concept. Sustainability 2019, 11, 5606. [CrossRef] 
15. Hussain, F.; Hussain, R.; Wu, R.-S.; Abbas, T. Rainwater harvesting potential and utilization for artificial recharge of groundwater using recharge wells. Processes 2019, 7, 623. [CrossRef]

16. Kisakye, V.; Van der Bruggen, B. The viability of artificial surface treatments as a mechanism for domestic rain water harvesting. Phys. Chem. Earth Parts A/B/C 2018, 107, 8-18. [CrossRef]

17. Vialle, C.; Busset, G.; Tanfin, L.; Montrejaud-Vignoles, M.; Huau, M.C.; Sablayrolles, C. Environmental analysis of a domestic rainwater harvesting system: A case study in France. Resour. Conserv. Recycl. 2015, 102, 178-184. [CrossRef]

18. Morales-Pinzón, T.; Lurueña, R.; Rieradevall, J.; Gasol, C.M.; Gabarrell, X. Financial feasibility and environmental analysis of potential rainwater harvesting systems: A case study in Spain. Resour. Conserv. Recycl. 2012, 69, 130-140. [CrossRef]

19. ISO (International Organization for Standardization). 14040:2006_Environmental Management_Life Cycle Assessment—Principles and Framework; ISO: Geneva, Switzerland, 2006.

20. ISO (International Organization for Standardization). 14044:2006-Environmental Management-Life Cycle AssessmentRequirements and Guidelines; ISO: Geneva, Switzerland, 2006.

21. ISO (International Organization for Standardization). 15686-5:2017-Buildings and Constructed Assets—Service Life Planning-Part 5: Life-Cycle Costing; ISO: Geneva, Switzerland, 2017.

22. Gluch, P.; Baumann, H. The life cycle costing (LCC) approach: A conceptual discussion of its usefulness for environmental decision-making. Build. Environ. 2004, 39, 571-580. [CrossRef]

23. Stephenson, A.L.; Von Blottnitz, H.; Brent, A.C.; Dennis, J.S.; Scott, S.A. Global warming potential and fossil-energy requirements of biodiesel production scenarios in South Africa. Energy Fuels 2010, 24, 2489-2499. [CrossRef]

24. Mohamad, R.S.; Verrastro, V.; Cardone, G.; Bteich, M.R.; Favia, M.; Moretti, M.; Roma, R. Optimization of organic and conventional olive agricultural practices from a Life Cycle Assessment and Life Cycle Costing perspectives. J. Clean. Prod. 2014, 70, 78-89. [CrossRef]

25. Buratti, C.; Fantozzi, F. Life cycle assessment of biomass production: Development of a methodology to improve the environmental indicators and testing with fiber sorghum energy crop. Biomass Bioenergy 2010, 34, 1513-1522. [CrossRef]

26. Figueiredo, F.; Castanheira, E.G.; Freire, F. Life-cycle assessment of irrigated and rainfed sunflower addressing uncertainty and land use change scenarios. J. Clean. Prod. 2017, 140, 436-444. [CrossRef]

27. Romeiko, X.X. A comparative life cycle assessment of crop systems irrigated with the groundwater and reclaimedwater in Northern China. Sustainability 2019, 11, 2743. [CrossRef]

28. Eshel, G.; Martin, P.A. Diet, energy, and global warming. Earth Interact. 2006, 10, 1-17. [CrossRef]

29. WFP. Water Harvesting in Practice: Towards Building Resilient Livelihoods in Semi-Arid Zones. In Field Practitioners Guide No. 2. Rural Resilience; World Food Programme: Nairobi, Kenya, 2018.

30. Philp, M.; Mcmahon, J.; Heyenga, S.; Marinoni, O.; Jenkins, G.; Maheepala, S.; Greenway, M. Review of Stormwater Harvesting Practices; Urban Water Security Research Alliance Technical Report No. 9; The Urban Water Security Research Alliance: City East, QLD, Australia, 2008. Available online: https:/ / publications.csiro.au/rpr/download?pid=procite:6057d2b6-42b7-4d03-9fd7 -ddd451b9d269\&dsid=DS1 (accessed on 4 March 2021).

31. Avnimelech, Y. Control of microbial activity in aquaculture systems: Active suspension ponds. World Aquac. Rouge 2003, 34, 19-21.

32. Ghimire, S.R.; Johnston, J.M. Holistic impact assessment and cost savings of rainwater harvesting at the watershed scale. Elementa 2017, 5, 9. [CrossRef] [PubMed]

33. Rigamonti, L.; Borghi, G.; Martignon, G.; Grosso, M. Life cycle costing of energy recovery from solid recovered fuel produced in MBT plants in Italy. Waste Manag. 2019, 99, 154-162. [CrossRef]

34. Brandão, M.; Clift, R.; Basson, L. A life-cycle approach to characterising environmental and economic impacts of multifunctional land-use systems: An integrated assessment in the UK. Sustainability 2010, 2, 3747-3776. [CrossRef]

35. Labaronne-Citaf Website. Available online: labaronne-citaf.com (accessed on 10 January 2021).

36. Leffio, D. Personal comunication. 2021.

37. Goedkoop, M.; Heijungs, R.; Huijbregts, M.; De Schryver, A.; Struijs, J.; Van Zelm, R. ReCiPe 2008. A Life Cycle Impact Assessment Method which Comprises Harmonised Category Indicators at the Midpoint and the Endpoint Level; Ministerie van VROM Rijnstraat: Den Haag, The Netherlands, 2009; Volume 1, pp. 1-126.

38. Palmieri, N.; Suardi, A.; Alfano, V.; Pari, L. Circular economy model: Insights from a case study in south Italy. Sustainability 2020, 12, 3466. [CrossRef]

39. Pari, L.; Suardi, A.; Stefanoni, W.; Latterini, F.; Palmieri, N. Environmental and economic assessment of castor oil supply chain: A case study. Sustainability 2020, 12, 6339. [CrossRef]

40. Baum, R.; Bieńkowski, J. Eco-efficiency in measuring the sustainable production of agricultural crops. Sustainability 2020, 12, 1418. [CrossRef]

41. Palmieri, N.; Suardi, A.; Latterini, F.; Pari, L. The eucalyptus firewood: Understanding consumers' behaviour and motivations. Agriculture 2020, 10, 512. [CrossRef]

42. Palmieri, N.; Suardi, A.; Pari, L. Italian consumers' willingness to pay for eucalyptus firewood. Sustainability 2020, 12, 2629. [CrossRef]

43. Moore, T.L.C.; Hunt, W.F. Predicting the carbon footprint of urban stormwater infrastructure. Ecol. Eng. 2013, 58, 44-51. [CrossRef] 
44. Ghimire, S.R.; Johnston, J.M.; Garland, J.; Edelen, A.; Ma, X.C.; Jahne, M. Life cycle assessment of a rainwater harvesting system compared with an AC condensate harvesting system. Resour. Conserv. Recycl. 2019, 146, 536-548. [CrossRef] [PubMed]

45. Morales-Pinzón, T.; Rieradevall, J.; Gasol, C.M.; Gabarrell, X. Modelling for economic cost and environmental analysis of rainwater harvesting systems. J. Clean. Prod. 2015, 87, 613-626. [CrossRef]

46. Devkota, J.; Schlachter, H.; Apul, D. Life cycle based evaluation of harvested rainwater use in toilets and for irrigation. J. Clean Prod. 2015, 95, 311-321. [CrossRef]

47. Arrivas Bajardi, C.; Fiore, M.; Breedveld, L.; Giaimo, L.; Notaro, A. Certifcazione Ambientale di Prodotti Agroalimentari LCA Dell'olio D'oliva; 2009. Available online: http://www.to-be.it/wp-content/uploads/2015/07/LCA-dellolio-doliva.pdf (accessed on 4 March 2021).

48. Ghimire, S.R.; Johnston, J.M.; Ingwersen, W.W.; Hawkins, T.R. Life Cycle Assessment of Domestic and Agricultural Rainwater Harvesting Systems. Environ. Sci. Technol. 2014, 48, 1-27. [CrossRef]

49. Lasage, R.; Verburg, P.H. Evaluation of small scale water harvesting techniques for semi-arid environments. J. Arid Environ. 2015, 118, 48-57. [CrossRef]

50. Deshmukh, G.; Hardaha, M.K.; Ahirwar, S.K. A case study on rain water harvesting technologies for tribal area of Madhya Pradesh, India. Plant Arch. 2016, 16, 151-156.

51. Reddy, K.S.; Ricart, S.; Maruthi, V.; Pankaj, P.K.; Krishna, T.S.; Reddy, A.A. Economic Assessment of Water Harvesting Plus Supplemental Irrigation for Improving Water Productivity of a Pulse-Cotton Based Integrated Farming System in Telangana, India. Irrig. Drain. 2020, 69, 25-37. [CrossRef]

52. Kumar, S.; Ramilan, T.; Ramarao, C.A.; Rao, C.S.; Whitbread, A. Farm level rainwater harvesting across different agro climatic regions of India: Assessing performance and its determinants. Agric. Water Manag. 2016, 176, 55-66. [CrossRef] 